Ю. В. Єловська

\title{
КОНТАКТНІ ТАБУ В КОМУНІКАТИВНІЙ ПОВЕДІНЦІ УКРАЇНЦІВ (НА МАТЕРІАЛІ ПОВІСТІ М. КОЦЮБИНСЬКОГО «ТІНІ ЗАБУТИХ ПРЕДКІВ»)
}

Єловська Ю. В. Контактні табу в комунікаційній поведінці українців (на матеріалі повісті М. Коцюбинського «Тіні забутих предків»).

У статті на матеріалі твору М. М. Коцюбинського «Тіні забутих предків» розглядається зв'язок контактних табу як різновиду комунікативних табу 3 містичними, релігійними й міфологічними уявленнями українців.

Ключові слова: комунікація, комунікативні табу, контактні табу, комунікативна поведінка.

(c) Ю. В. Єловська, 2012. 
Еловская Ю. В. Контактные табу в коммуникативном поведении украинцев (на материале повести М. Коцюбинского «Тени забытых предков»).

В статье рассматривается на материале произведения М. М. Коцюбинского «Тени забытых предков» проблема связи контактных табу как разновидности коммуникативных табу с мистическими, религиозными и мифологическими представлениями украинцев.

Ключевые слова: коммуникация, коммуникативные табу, контактные табу, коммуникативное поведение.

Yelovska Yu. V. Contact taboos in communicative behavior of Ukrainians (based on M. Kotsyubynskyi's "Shadows of Forgotten Ancestors").

This article deals with the problem of interconnection between the contact taboos as a form of communicative taboos and Ukrainians' mystic, religion and mythological beliefs on the material of M. Kotsubynsky's "Shadows of Forgotten Ancestors".

Key words: communication, communicative taboos, contact taboos, communicative behavior.

Культура української нації акумулює в собі давні світоглядні уявлення та вірування, які визнавали могутню силу слова й магічних обрядів. І. Чернова зазначає, що на українську духовну культуру впливає християнська релігія й містика [7, с. 712]. Беззаперечним $\epsilon$ i той факт, що ці особливості української культури накладають суттєвий відбиток на мовленнєву поведінку українців. Існує чимала кількість мовних, тематичних i контактних табу, пов'язаних iз релігійним і міфологічним світобаченням нашого народу.

Проблема виділення комунікативних табу, тлумачення цього явища і підходи до їх класифікації є об’єктом вивчення як вітчизняних, так і зарубіжних науковців (Ф. Бацевич, Л. Фроляк, І. Мілєва, Р. Газізов, В. Кашкін, Я. Попова, О. Кострова, М. Тульнова та ін.). Багато наукових розвідок присвячено дослідженню мовних $\mathrm{i}$ тематичних зразків комунікативних табу та їх зв'язку з культурою й ментальністю нації. Однак питанню саме контактних табу і їх відображенню в процесі комунікації приділяється незначна увага.

Я. Попова характеризує табу як заборони на вживання певних слів, тем і уникання окремих комунікантів, обумовлені цензурою, етикетом, соціально-політичними, релігійними й культурними чинниками [3]. Ф. Бацевич виокремлює різні види комунікативних табу, а саме: мовні (заборони на вживання слів, словосполучень, що $є$ небажаними у спілкуванні), тематичні (заборони на обговорення неприйнятних і заборонених тем у певному соціумі або соціальній групі) й контактні (уникання осіб, з якими не варто зустрічатися, а надто спілкуватися) [1, с. 264].

( ) Ю. В. Єловська, 2012. 
За Ф. Бацевичем, контактні табу передбачають заборону на будь-які форми міжособистісного спілкування в межах певної національної лінгвокультурної спільноти [1, с. 264].

Колективній свідомості українського народу властива віра в магічну силу самого слова, підсилену особою, що його вимовляє, яка грунтується на давніх магічних, міфологічних i світоглядних уявленнях. Думка, що слова й певні особистості притягують відповідні події, зокрема негативні, міцно тримається у свідомості українців. Чимала кількість прислів’їв застерігає від уживання в побуті таких слів, як чорт, дідько, бic, лихо, оскільки подібна комунікативна поведінка може спровокувати появу негативних наслідків у вигляді жахливих подій та невдач або зустрічей із потойбічними силами, які, зі свого боку, не пророкують нічого доброго: Казало лихо: не буть добру (2, с. 158); Не займай біса, бо лихо займеш, а то й двоє (2, с. 284); Не проси дідька в гості, він прийде непрошений (2, с. 286); Не клич біди до себе, вона сама прийде до тебе (1, с. 28); Не проти ночі чорта згадуй (1, с. 232).

Варто зазначити, що зразки контактних табу як різновиду комунікативних знайшли своє відображення i у творчості багатьох українських письменників, зокрема М. Коцюбинського, І. Котляревського, Л. Українки та ін. Чималу кількість заборон на будь-яке міжособистісне спілкування, що грунтується на містичних, релігійних та міфологічних уявленнях українців, знаходимо у творі М. Коцюбинського «Тіні забутих предків». У повісті представлено передусім заборони на спілкування 3 представниками потойбічного світу й людьми 3 надприродними можливостями, оскільки комунікативний акт із ними може спричинити негативні для комуніканта наслідки. Окрему групу контактних табу складають заборони на будь-яке спілкування під час виконання різноманітних побутових дій, наділених магічним смислом.

Головний герой повісті Іван Палійчук протягом усього життя стикається з міфічними персонажами, створеними уявою українського народу. 3 самого дитинства хлопець мав чітко сформовану систему знань про потойбічний світ, так що навіть рідна мати дивувалася і 3 острахом піддавала сумніву, чи був він іiі кровною дитиною, а не одмінком (дитина, підмінена нечистою силою) [4, с. 216]: Не раз вона з ляком думала навіть, щуо то не од неї дитина. Не «сокотилася» баба при злогах, не обкурила десь хати, не засвітила свічки - $і$ хитра бісиия 
встигла обміняти ї̈ дитину на своє бісеня (3, с. 205).

Містичне буття, що 3 дитинства крокувало поряд із життям Івана, не минуло його й у дорослому віці. Перебуваючи на полонині, Іван не раз зустрічав демонічних істот і дивом лишався живим, хоча й достатньо зляканим (тяжкий сон із спогадами про Марічку, що напускала мара на полонині; перші поклики лісної мавки).

Зазначимо, що, за українськими повір'ями, зустрічі 3 представниками надприродного світу (злі духи, русалки, чугайстри, нявки, арідник, щезник) здебільшого віщують загибель тим, хто наважився їх потурбувати. Але в подібних випадках вирішальним може бути знання особливих правил спілкування: необхідно знати, що треба говорити, а яких слів промовляти не можна. Так, наприклад, стрітивши русалку, щоб убезпечити своє життя і не стати потопельником, людина на запитання Полин чи петрушка? має відповідати Полин (водяні німфи ненавидять цю рослину). Тоді русалки тікають і не завдають ніякої шкоди. Полин є табуйованим словом для русалок i, відповідно, оберегом для людини. I, навпаки, відповідь Петрушка в комунікативному акті 3 русалкою виступає для людини мовним табу, оскільки є смертним вироком для неї, адже в такому разі русалки говорять: Ти моя душка,лоскочуть і затягують нещасного у воду [5, с. 396].

Головний герой повісті М. Коцюбинського був дотичний до демонічних істот протягом усього життя, проте лише безпосередній комунікативний контакт із ними призводить до його загибелі.

У віці 7 років Іван уперше, коли випасав вівці, побачив щезника. Хлопець був зачарований дивною мелодією магічної флояри і не міг втриматися, щоб не дізнатися, звідки лунала та чарівна пісня. Побачивши виконавця, малий зрозумів, що стрівся зі злим духом лісу, i хоча під час зустрічі комунікації як такої між ними не відбулося, проте навіть зоровий контакт із цим міфічним створінням мав значний вплив на дитину: Він хтів тікати - й не міг. Сидів прикутий на місці $і$ німо кричав од холодного жаху, а коли врешті видобув голос, щезник звинувся і пропав раптом у скелі, а цапи обернулись в коріння дерев, повалених вітром (3, с. 208). Нагадаємо, що щезник, за народними уявленнями, є одним із представників злих лісових духів, це свого роду різновид чорта i, відповідно, зустріч із ним веде людину до загибелі [2, с. 655]. Оскільки між комунікантами відбувся лише візуальний контакт, а не безпосередньо комунікативний акт, наслідки цієї зустрічі за ступенем негативного впливу можна оцінювати як помірно легкі.

( Ю. В. Єловська, 2012. 
Зустріч із лісовою мавкою стає для героя фатальною. Народні повір'я описують цих демонічних істот як таких, що можуть приймати подобу дівчини, у яку був закоханий парубок, і говорити іiі голосом. Перше стрічає Іван мавку, що схожа на Марічку, уві сні, який насилає на нього мара. Вдруге нявка приходить і кличе його вже на полонині, проте хлопець вчасно розуміє, що се його кличе лісна. I, хрестячи груди та озираючись лячно, він повертає до стаї (3, с. 227). Парубок, хоча й не вступає в акт комунікації з бісицею, проте порушує контактне табу, що існує в його свідомості, почавши йти на голос мавки. Іван міг упасти в прірву і втратити життя, однак спинився за крок від загибелі. Втретє він охоче слідує за бісицею, незважаючи на те що чітко розуміє, наскільки небезпечне таке спілкування, і чим може скінчитися ця зустріч: Свідомість його двоїлась. Чув, щзо коло його Марічка, $і$ знав, щзо Марічки нема на світі, щзо се хтось інший веде його у безвісті, у недеї, щзоб там загубити (3, с. 241).

Контактні табу існують і для істот потойбічного світу. Так, найстрашнішим ворогом нявок є чугайстер, оскільки зустріч із ним пророкує лісним негайну смерть. За повір'ям, чугайстер ловить i роздирає їх, у той час як для людей зустріч із ним є безпечною: він чемно запрошує в танок, а потім відпускає [5, с. 391]. Полюючи на мавок, чугайстер тим самим охороняє людей, а інколи й рятує їм життя. Так, наприклад, у творі автор показує зустріч Івана 3 чугайстром саме тоді, коли його намагалася завести в хащі нявка, що взяла подобу Марічки. Остерігаючись доброго лісного духу, вона швидко зникла так несподівано ц̆ чудно, щзо Іван не встиг спам'ятатись (3, с. 242).

Містичні істоти не єдині комуніканти, зустрічей із якими, за народними уявленнями, слід уникати. Особливу категорію становлять також люди, наділені надприродними можливостями, а саме відьми, відьмаки, чаклуни тощо. Сила їхніх слів набагато сильніша, ніж у звичайної людини.

Такі особи експліцитно можуть і не висловлювати прокльону чи бажати лиха, проте часом висловлювання, що мають загалом позитивний зміст, дають протилежний результат.

М. Коцюбинський змальовує комунікативну поведінку вченої відьми в образі сусідки Палійчуків Хими: - Hy i сусіди дав нам панбіг! - жалілась вона (Палагна) чоловікові. - Війшла даві в притулу Хима, глянула на ягнєта та як сплесне в долоні: «їй! Які вони файні!» 
На, маєш, гадаю собі. Не встигла та за поріг, а двоє ягнєт закрутилось на місиі - та й вже по них... Ігій на тебе, відьмо... (3, с. 229).

Здавна в народній свідомості живе віра в пристріт - магічну шкоду, заподіяну самою зустріччю 3 лихою людиною. Зазначимо також, що важливими і магічно впливовими під час таких контактів виявляються не слова, а почуття та думки. За народними уявленнями, магічну шкоду може спричинити сам факт появи певної людини, наприклад, відьми, іiі погляд тощо. У випадку 3 худобою Палійчуків відьмі достатньо було заздрісно подивитися на тварин і сказати цілком позитивну фразу Ïй! Які вони файні! (худоба дійсно була файною), щоб нанести шкоду.

Хима - не єдиний у творі образ людини, яка володіє надприродними силами. 3 другого боку, на найближчім горбі сусідив Юра. Він був як бог, знаючий і сильний, той градівник $і$ мольфар.... Од його слова гинула зразу худоба, сохла й чорніла, як дим, людина, він міг наслати смерть і життя, розігнать хмару $і$ сперти град, вогнем чорного ока спопелить ворогів $i$ запалити в жіночому сериі кохання (3, с. 229, 235).

Мольфар, на відміну від відьми, може не тільки завдавати шкоди людині, а й приносити користь. Юра заклинає грозову хмару, його слово спиняє грозу й рятує худобу й сіножатки від граду. У розмові з Палагною він розказує жінці, як може чарівник заподіяти будь-кому шкоду, маючи лише глиняну ляльку й тикнувши в неї пальцями: - Б’ю кілок тут, - шептав зловісно, - $і$ сохнуть руки та й ноги. В живіт - карається на живіт; не годен їсти...-А єкби у голову вбив? - питала иікаво Палагна. - Тоді гине в той мах... (3, с. 239). В основі подібних магічних дій - інший принцип магії: чарівник діє на людину через предмет, подібний до неї або належний їй. Отже, навіть якщо людина й дотримується контактних заборон, це не може гарантувати їй уникнення магічної шкоди.

Зауважимо, що контактні табу не обмежують коло комунікантів лише людьми й міфічними істотами потойбічного світу. За певних умов навіть звичайні побутові дії набувають нового статусу, за яким будь-яка комунікація забороняється або взагалі, або на певний проміжок часу.

У творі М. Коцюбинського, коли головний герой уперше приходить на полонину, щоб найнятися у вівчарі, і вітає ватага, очікуваної відповіді він не отримує доти, доки не з'явився вогонь, який той видобував: - Слава Ісусу! - привітався Іван. Але йому нічого не одповіли (3, с. 216).

За уявленнями українців, під час виконання цього священного ритуалу ніхто не повинен турбувати ватага, оскільки видобування ( Ю. В. Єловська, 2012. 
святого вогню, що має силу проти усього нечистого, не можна осквернити будь-якими зайвими й небажаними висловлюваннями.

Подібна комунікативна заборона торкається й процесу приготування їжі, а саме будзу з молока: Tenер має бути тихо у стаї, двері замкнені, $і$ навіть спузар не сміє кинуть оком на молоко, поки там твориться щьось, поки ватаг чаклує. Все наче застигло в німому чеканні, бербениці затайли у собі голос, притайлись будзи на полицях, поснули сном чорним стіни $і$ лави, вогонь ледве диха, $i$ навіть дим соромливо тікає в вікно (3, с. 222). Тиша є неодмінною умовою цього «чаклування», інакше будз не вдасться, а це означатиме, що вівчарі лишаться без вечері. Забороняється не тільки мовленнєве спілкування, а й навіть зоровий контакт. I не тільки 3 тим, хто чаклує, а й із предметом магічних дій.

Отже, контактні табу як різновид комунікативних табу тісно пов'язані 3 містичними, релігійними й міфологічними уявленнями українського народу. Такі заборони мають на меті убезпечити життя людини від можливих негативних наслідків, що можуть бути спричинені спілкуванням із представниками потойбічного світу та особами 3 надприродними можливостями, що яскраво зображено у творі М. Коцюбинського «Тіні забутих предків». Контактні табу також $є$ важливою умовою виконання низки інших видів діяльності, зокрема магічних ритуалів у побуті. Контактні обмеження можуть охоплювати не лише комунікантів-людей, а й звичайні предмети побуту, які в певних ситуаціях стають магічно значущими. Істотний вплив традицій i вірувань на формування контактних табу в мовленнєвій поведінці українців, без сумніву, викликає науковий інтерес і потребує подальшого дослідження.

\section{Література}

1. Бацевич Ф. С. Основи комунікативної лінгвістики : [підручник] / Флорій Сергійович Бацевич - К. : Академія, 2004. - 344 с.

2. Жайворонок В. Знаки української етнокультури: словник-довідник / В. Жайворонок. - К. : Видавництво «Довіра», 2006. - 706 с.

3. Попова Я. В. Табу в сфере коммуникативно-языковой актуализации [Електронний ресурс] / Я. В. Попова // Язык. Культура. Общество. - 2010. Вып. 2. Режим доступу до журналу : http://yazik.info/2010-14.php

4. Українська минувшина : ілюстрований етнографічний довідник / [уклад. А. П. Пономарьов, Л. Ф. Артюх, Т. В. Косміна та ін.]. - К. : Либідь, 1994. - 256 с.

5. Українці: народні вірування, повір'я, демонологія / [упоряд., прим., та біогр. нариси А. П. Пономарьова, Т. В. Косміна, О. О. Боряк]. - К. : Либідь, 1991. - 640 с.

6. Фрэзер Д. Д. Золотая ветвь: Исследование магии и религии / Джеймс Джордж 
Фрэзер; [пер. с англ.]. - М. : Политиздат, 1986. - 703 с.

7. Чернова I. Містичне як вияв авторської свідомості у сучасній українській фантастиці / Iрина Чернова // SOUČASNÁ UKRAJINISTIKA PROBLÉMY JAZYKA, LITERATURY A KULTURY : IV. Olomoucké sympozium ukrajinistů, 28-30. srpna 2008. - C. 711-715.

\section{Список використаних джерел}

1. Українські народні прислів'я та приказки / [упоряд. В. Бобкова, Й. Багмут, А. Багмут]. - К. : Держ. вид. худ. літ-ри, 1963. - 790 с.

2. Прислів'я та приказки : Взаємини між людьми / [упоряд. М. Пазяк].К. : Наукова думка, 1991. - 440 с.

3. М. М. Коцюбинський Твори : у 2-х т. / Михайло Михайлович Коцюбинський. К. : Наукова думка, 1988. - Т. 2. - 496 с.

Стаття надійшла до редакції 12.10.2012 p. 